\title{
Supervisi Klinik Sebagai Upaya Meningkatkan Kemampuan Guru dalam Mengelola Pembelajaran di SMA Negeri 8 Gowa
}

\author{
Islamuddin \\ Kepala UPT SMA Negeri 8 Gowa - Provinsi Sulawesi Selatan \\ *Corresponding Author. Email: islamuddindaud@gmail.com
}

\begin{abstract}
This study aims to improve the ability of teachers to manage learning through clinical supervision. This study uses school action research with the research subjects being teachers at SMA Negeri 8 Gowa. This research instrument uses a questionnaire, observation, and documentation. The data analysis technique used descriptive qualitative and quantitative analysis. The results of this action research indicate that through clinical supervision carried out by the school principal, it has been able to improve the ability of teachers to manage learning, especially in the preparation of learning implementation plans, the ability to manage classes, as well as the implementation of evaluation and assessment. Based on the assessment format data in this study, the number of teachers who scored (70-85) in the high grade category (B) was 6 teachers or $(85.71 \%)$.

Abstrak: Penelitian ini bertujuan untuk meningkatkan kemampuan guru dalam mengelola pembelajaran melalui supervisi klinik. Penelitian ini menggunakan penelitian tindakan sekolah dengan subyek penelitian adalah guru-guru di SMA Negeri 8 Gowa. Instrument penelitian ini menggunakan angket, observasi, dan dokumentasi. Teknik analisis data menggunakan analisis deskriptif kualitatif dan kuantitatif. Hasil penelitian tindakan ini menunjukkan bahwa melalui supervisi klinik yang dilakukan oleh kepala sekolah telah mampu meningkatkan kemampuan guru dalam mengelola pembelajaran khususnya dalam penyusunan rencana pelaksanan pembelajaran, kemampuan mengelola kelas, serta pelaksanaan evaluasi dan penilaian. Berdasarkan data format penilaian dalam penelitian ini bahwa jumlah guru yang mendapat nilai (70-85) dengan kategori nilai tinggi (nilai B) sebanyak 6 orang guru atau $(85,71 \%)$.
\end{abstract}

Article History

Received: 05-07-2021

Revised: 06-08-2021

Accepted: 12-09-2021

Published: 05-10-2021

\section{Key Words:}

Manage Learning, Clinical Supervision, Teachers.

\section{Sejarah Artikel}

Diterima: 05-07-2021

Direvisi: 06-08-2021

Disetujui: 12-09-2021

Diterbitkan: 05-10-2021

\section{Kata Kunci:}

Pengelolaan Pembelajaran, Supervisi Klinik, Guru.

How to Cite: Islamuddin, I. (2021). Supervisi Klinik sebagai Upaya Meningkatkan Kemampuan Guru dalam Mengelola Pembelajaran di SMA Negeri 8 Gowa. Jurnal Paedagogy, 8(4), 482-489. doi:https://doi.org/10.33394/jp.v8i4.4013

\section{Pendahuluan}

Pendidikan nasional bertujuan mencerdaskan kehidupan bangsa dan mengembangkan manusia Indonesia seutuhnya, yaitu manusia yang beriman dan bertaqwa kepada Tuhan Yang Maha Esa dan berbudi pekerti luhur, memiliki pengetahuan dan keterampilan, kesehatan jasmani dan rohani, kepribadian yang mantap dan mandiri sendiri serta rasa tanggungjawab kemasyarakatan dan kebangsaan (UU RI No. 20 tahun 2003 Bab II pasal 3). Berbagai upaya yang telah dilakukan oleh pemerintah pusat dan kabupaten/kota dalam rangka peningkatan mutu pendidikan nasional misalnya dengan menyiapkan alokasi dana yang besar baik dalam APBN maupun APBD, meningkat kan kemampuan tenaga pendidik (guru) serta tenaga kependidikan lainnya melalui penataran atau pelatihan, demikian pula dalam hal pengembangan dan penyempurnaan kurikulum, serta penelitian yang berkaitan dengan peningkatan mutu pendidikan (Puskur-Balitbang, 2006).

Tenaga pendidik (guru) adalah merupakan ujung tombak pendidikan yang berada di garis terdepan (di kelas) yang memiliki pengaruh yang sangat besar terhadap kemajuan 
pendidikan, selain itu guru juga sangat besar pengaruhnya terhadap prilaku dan belajar peserta didik (siswa) yang memiliki kecenderungan meniru serta mencontoh atau meneladani dan beridentifikasi. Hal-hal yang berpengaruh itu antara lain: otoritas akademis dan non akademis, kesehatan mental, cita-cita dan sikap, kesenangan, serta suasana kelas yang diciptakan oleh guru dan tindakan-tindakannya. Pengaruh ini paling sangat dirasakan oleh siswa baik pada perkembangan intelektual maupun terhadap peningkatan motivasi belajar siswa, dan emosionalnya.

Seorang pendidik (guru) harus dapat melaksanakan tugasnya dengan baik, hal ini sejalan dengan tugas dan fungsinya sebagai ujung tombak dalam pembelajaran di kelas karena salah satu kemampuan guru yang harus terpenuhi adalah kemampuan paedagogik. Kunandar (2007) mengemukakan bahwa seorang guru pemula diperlukan tiga keahlian yang harus dipersiapkan sebelum mengajar di kelas, yakni: (1) pengetahuan tentang cara mengelola kelas, (2) Pengetahuan dalam mata pelajaran atau penguasaan bahan ajar, dan (3) Pembelajaran tentang latar belakang sosiologikal para siswa yang dididik.

Berdasarkan pengamatan dan pengalaman dalam melaksanakan tugas sebagai seorang kepala sekolah atau supervisior di sekolah ditemukan bahwa pada diri guru bahwa pada masa-masa awal pengalaman mengajarnya sebagai seorang guru pemula diliputi berbagai macam problema salah satunya adalah munculnya tekanan mental. Tekanan mental tersebut jika ditelusuri maka yang menjadi sumber penyebabnya adalah ketidak mampuan seseorang dalam menguasai metode serta bahan ajar yang akan diajarkannya karena hal ini merupakan hal yang dianggap sebagai sesuatu yang masih sangat baru dalam pengalaman hidupnya sebagai seorang guru pemula, tetapi yang pasti bahwa problema ini merupakan dinamika psikologis yang senantiasa menyertai di dalam proses penyesuaian diri guru dalam dunia barunya sebagai pendidik, yaitu berada di kelas dalam melaksanakan tugasnya sebagai seorang guru yang baik dan bertanggungjawab.

Sebagai seorang guru pemula dalam melaksanakan tugas mengajar di kelas selalu dihinggapi atau diselimuti perasaan khawatir dan was-was, perasaan seperti ini dilandasi dengan rasa kegagalan atau ketidakberhasilan dalam melaksanakan tugas mengajar. Hal seperti ini terjadi karena disebabkan oleh keterbatasan pengalaman cara mengajar yang baik, sehingga sering timbul pertanyaan-pertanyaan dalam dirinya, seperti: Bagaimana saya mengajar di kelas, materi apa yang harus saya ajarkan, alat atau media apa yang saya bisa digunakan, apa yang saya lakukan apabila materi yang diajarkan sudah selesai sementara waktu masih ada dan sebagainya.

Tyler dalam Ella Yulaewati (2005) mengemukakan bahwa kurikulum adalah prinsipprinsip dan prosedur bagi perencanaan, implementasi, evaluasi, dan pengelola atu program pendidikan. Silabus adalah suatu aplikasi atau perincian materi yang akan diajarkan dalam suatu program berikut susunan atau aturan yang akan diajarkan. Kurikulum 2013 adalah seperangkat rencana dan pengaturan tentang kompetensi dan hasil belajar yang harusa dicapai oleh siswa, penilaian, kegiatan belajar dan pemberdayaan sumber daya pendidikan dalam pengembangan kurikulum sekolah. Rumusan kompetensi dalam kurikulum 2013 merupakan pertanyaan apa yang diharapkan dapat diketahui, disikapi atau dilakukan siswa dalam setiap tingkatan kelas atau sekolah, sekaligus menggambarkan kemajuan siswa yang dicapat secara bertahap dan berkelanjutan untuk peserta didik menjadi kompeten atau memiliki kompetensi.

Peran seorang guru dalam pengembangan silabus sangat penting mengingat hanya gurulah yang mengetahui perbedaan kemampuan, kompetensi, minat, kepribadian, sikap, dan motivasi belajar peserta didiknya (Jamilan, 2017; Supatni, 2017; Zainudin, 2016). Untuk itu guru dituntut secara kreatif dan terus menerus mengkaji silabus yang dibuat dan mampu 
mengembangkannya sesuai dengan kebutuhan dan perbedaan kompetensi peserta didiknya (Kamaruddin, 2021; Muhsin, 2021; Wahyuni, 2021).

Mulyasa (2004) berpendapat bahwa peran guru dalam mengimplementasikan silabus dapat ditinjau dari dua segi yaitu: 1) dari segi proses, dan 2) dari hasil. Dari segi proses guru dikatakan berhasil apabila mampu melibatkan sebagian peserta didik secara aktif baik fisik, mental, maupun social dalam proses pembelajaran, disamping itu dapat dilihat dari gairah dan semangat mengajarnya serta adanya rasa percaya diri dalam melaksanakan proses belajar mengajar. Dari segi hasil, guru dikatakan berhasil apabila pembelajaran yang dilakukan mampu mengadakan perubahan perilaku sebagian besar anak didiknya ke arah yang lebih baik. Untuk itu guru harus selalu mempunyai sikap positif terhadap siswanya dan diaplikasikan dalam perilakunya. Untuk melakukan sikap positif di atas, guru harus mampu mengkordinasikan lingkungan belajar yang menyenangkan bagi siswanya, sehingga mereka termotivasi dalam melaksanakan tugas mengajamya dengan sebaik-baiknya.

Proses pembelajaran yang harus dilakukan oleh guru dalam melaksanakan tugasnya dengan baik di kelas yaitu menyiapkan persiapan mengajar dalam pembelajaran, serta melaksanakan program pembelajaran yang telah direncanakan, serta memberikan refleksi Adapun penelitian ini bertujuan untuk meningkatkan kemampuan guru dalam mengelola pembelajaran melalui supervisi klinik.

\section{Metode Penelitian}

Penelitian ini merupakan penelitian tindakan sekolah (school action research) sebagai salah satu upaya peningkatan kemampuan guru dalam mengelola pembelajaran di Sekolah Menengah Atas (SMA), khusunya di SMA Negeri 8 Gowa. Dalam pelaksaaannya dilakukan dalam berbagai tahap melalui kegiatan-kegiatan yang dilakukan oleh guru di kelas dan diamati secara langsung oleh peneliti sebagai seorang kepala sekolah atu supervisior. Hal ini dilakukan untuk melihat langsung kelemahan dan kelebihan kegiatan proses belajar mengajar yang dilakukan oleh guru. Selain itu juga dilakukan refleksi bersama guru yang diamati guna mendiskusikan kelemahan dan kelebihan yang dilakukan oleh guru sebagai subjek penelitian tindakan selama proses belajar mengajar berlangsung.

Adapun data guru yang menjadi subjek penelitian tindakan Sekolah atau kepengawasan (PTS) ini dapat dilihat pada tabel 1 berikut:

Tabel 1. Data Guru Subjek PTS

\begin{tabular}{|c|c|c|c|}
\hline No & Guru Kelas & Mapel Yang Diampuh & Jumlah \\
\hline 1 & XI & Penjaskes & 1 orang \\
\hline 2 & XI & Ekonomi & 1 orang \\
\hline 3 & XI & Kimia & 1 orang \\
\hline 4 & XI & Fisika & 1 orang \\
\hline 5 & XI & Geografi & 1 orang \\
\hline 6 & XI & Kimia & 1 orang \\
\hline \multicolumn{2}{|r}{} & 6 Orang \\
\hline
\end{tabular}

Prosedur pelaksanaan tindakan dilakukan secara bertahap sebagai berikut: (1) membuat jadwal kunjungan di kelas untuk melakukan supervisi terhadap guru yang menjadi objek tindakan yang disesuaikan dengan jadwal pelajaran, (2). Mengundang guru guru yang akan disupervisi guna memberitahukan kepada mereka sehubungan dengan rencana pelaksanaan tindakan kepengawasan, (3). Membuat instrument (angket) yang akan diisi oleh guru yang menjadi objek tindakan, (4). Memberi instrumen kepada guru yang menjadi objek 
peneliti tindakan kepengawasan, (5). Mengumpulkan instrumen yang telah disi oleh guruguru yang menjadi objek tindakan kepengawasan, (6). Memantau guru-guru di kelas berdasarkan jadwal yang sudah dibuat dengan menggunakan format penilaian yang telah disiapkan, dan (7). Melakukan refleksi dengan cara memberikan kesempatan kepada guruguru mengenai hal-hal yang ditemukan pada saat guru melakukan kegiatan proses belajar mengajar di kelas, selanjutnya diberikan bimbingan oleh peneliti atau supervisior dengan melihat kekurangan/kelemahan guru-guru pada format penilaian yang telah diisi oleh peneliti.

Pelaksanaan tindakan kepengawasan ini dilakukan dalam dua siklus kegiatan yang terdiri dari empat langkah-langkah sebagai berikut: (1) Perencanaan, (2) Pelaksanaan, (3) Pengamatan, dan (4) Refleksi. Keempat langkah tersebut merupakan satu siklus artinya setelah langkah keempat sudah dilakukan maka dilanjutkan dengan pelaksanaan siklus berikutnya atau siklus II. Adapun teknik analisis data yang digunakan dalam penelitian ini adalah analisis deskriptif kualitatif dan kuantitatif.

\section{Hasil Penelitian dan Pembahasan}

Berdasarkan tujuan supervisi di sekolah, maka penelitian ini berfokus kepada kegiatan-kegiatan tentang penyusunan rencana pelaksanaan pembelajaran (RPP) atau desain pembelajaran, pelaksanaan pembelajaran di kelas, pemantauan langsung terhadap guru-guru di kelas, serta melakukan refleksi yang merupakan inti dari kegiatan pelaksanaan tindakan kepengawasan baik pada siklus I maupun siklus II. Sebagai persiapan utama yang telah dilakukan sebelumnya maka oleh peneliti melakukan pembahasan bersama terhadap fokus penelitian, penyusunan perangkat pembelajaran, pelaksanaan pembelajaran serta penialian atau evaluasi. Demi lancarnya pelaksanaan tindakan maka prosedur kerja yang ditempuh oleh peneliti sebagai implementasi tindakan yang telah dilaksanakan, yaitu sebagai berikut;

Pada siklus pertama kegiatan yang dilakukan oleh peneliti adalah: 1) melakukan pemantauan terhadap I orang guru Penjaskes dimana waktu pelaksanaannya dilakukan pada tanggal 23 Juli 2018 yang mengajar di kelas XI IPA2 dengan lama waktu pemantauan selama 2 jam pembelajaran (2X45 menit), pemantauan terhadap I orang guru yang mengajar ekonomi di kelas XI IPA1 pemantauannya dilakukan pada tanggal 24 Juli 2018 dengan lama waktu pemantauan selama 2 jam pembelajaran (2X45 menit), pemantauan terhadap I guru yang mengajar Kimia di kelas XI IPA3 pada tanggal 25 Juli 2018 dengan lama waktu pemantauan selama 2 jam pembelajaran (2X45 menit), dan 1 orang guru yang mengajar mata pelajaran Fisika di kelas XI IPA 1 pada tanggal 26 Juli 2018 dengan lama pemantauan 2 jam pelajaran (2x45 menit). Pemantauan tersebut dilakukan selama pelaksanaan siklus I dengan jumlah guru yang dipantau sebanyak 4 orang guru. (2) melakukan pemberian nilai terhadap guru yang sudah dipantau mengajar di kelas dengan mempertimbangkan kemampuan yang dimiliki oleh guru, (3) Melakukan refleksi terhadap temuan-temuan dalam pemantauan yang meliputi kekurangan dan kelemahan guru dalam melakukan kegiatan belajar mengajar di kelas guna perbaikan pada pertemuan selanjutnya, (4) selanjutnya guru membuat persiapan mengajar untuk pelaksanaan tindakan pada siklus II.

Pada pelaksanan siklus II kegiatan yang dilakukan oleh peneliti hampir sama dengan pelaksanaan siklus I karena siklus II merupakan perbaikan dan penyempumaan pada pelaksanaan siklus I. Adapun kegiatan yang dilaksanakan adalah sebagai berikut: 1) melakukan pemantauan terhadap 1 orang guru yang mengajar Penjaskes dimana waktu pelaksanaannya dilakukan pada tanggal 6 Agustus 2018 yang mengajar di kelas XI IPA 1 dengan lama waktu pemantauan selama 2 jam pembelajaran (2X45 menit), pemantauan terhadap guru yang mengajar ekonomi di kelas XI IPA 2 pada tanggal 7 Agustus 2018 
dengan lama waktu pemantauan selama 2 jam pembelajaran ( 2 x 45 menit). Pemantauan tersebut dilakukan selama pelaksanaan siklus Il dengan jumlah guru yang dipantau sebanyak 3 orang guru. (2) melakukan pemberian nilai terhadap guru yang sudah dipantau mengajar di kelas dengan mempertimbangkan kemampuan yang dimiliki oleh guru, (3) Melakukan refleksi terhadap temuan-temuan dalam pemantauan yang meliputi kekurangan dan kelemahan guru dalam melakukan kegiatan belajar mengajar di kelas. Berdasarkan uraian di atas, maka dapat dilihat hasil dan refleksi berlangsung secara terpadu melalui proses perencanaa, pelaksanaan, pengamatan, dan refleksi. Keempat langkah kegiatan tindakan tersebut merupakan satu kesatuan yang utuh baik dari pelaksanaan pertemuan tindakan dalam satu siklus maupun pertemuan dalam siklus I yang satu dengan siklus yang lain (siklus 11).

Diadakan daur ulang tersebut dilaksanakan sebagai upaya peneliti untuk meningkatkan kemampuan guru dalam mengelola Pembelajaran di sekolah utamanya pada jenjang sekolah menengah (SMA). Penekanan yang dianggap hal-hal mendasar seperti pendalaman pembuatan RPP ,penguasaan Pengelolaan pembelajaran (kelas), penguasaan dalam memilih bahan ajar, penguasaan. Dalam memanfaatkan media pembelajaran atau alat peraga serta penguasaan dalam penilaian dan evaluasi merupakan hal yang mendapat perhatian dari peneliti demikian pula terhadap guru yang supervisi untuk kegiatan pelaksanaan pembelajaran berikutnya. Sehingga guru-guru menjadi sarana pemantauan dapat merasakan manfaat dari pelaksanaan tindakan kepengawasan ini serta penilaian yang dilakukan oleh peneliti sebagai supervisor di kelas.

Dari hasil pelaksanaan tindakan siklus selama pemantauan di kelas, maka pada siklus 1 ini menunjukkan hasil yang belum maksimal karena dari 6 orang guru yang dipantau di kelas baru terdapat 2 orang guru $(28,57 \%)$ yang mampu mempersiapkan rencana pembelajaran dengan baik, demikian pula dalam hal mengimplementasikannya sedangkan 4 orang guru lainnya $(71,43 \%)$ yang belum mampu melakukan persiapan mengajar (RPP) dengan baik, dari hasil tersebut peneliti mengundang kembali guru-guru tersebut dengan maksud menyampaikan hal-hal yang merupakan kelemahan dan kekurangan yang dilakukan oleh selama melakukan proses pembelajaran. Selain menyampaikan kekurangan dan kelemahan peneliti juga memberikan bimbingan terhadap guru-guru bagaimana cara menyusun rencana pembelajaran dengan baik.

Data penelitian menunjukkan bahwa berdasarkan hasil penilaian yang dilakukan oleh peneliti sesuai formar penilaian maka terdapat 5 orang guru yang menjadi objek tindakan masih memperolen nilai antara 40-54 yang berarti nilai kategori kurang (D). hasil penilaian menunjukkan bahwa guru tersebut sangat kurang dalam melakukan persiapan mengajar penyusunan silabus, alat penilaian, penguasaan kelas, demikian pula dalam hal penggunaan waktu serta evaluasi atau penilaian.Siklus I. di awali dengan langkah-langKah 1). perencanaan. pada langkah Ini maka peneliti menyampaikan: a) rencana pelaksanaan kegiatan supervisi di kelas kepada guru-guru yang akan dipantau denga cara memberikan angket yang sudah dipersiapkan oleh peneliti hal ini dilakukan oleh peneliti untuk melihat kesiapan guru guru dalam melaksanakan pembelajaran di kelas. b). peneliti membuat format penilaian sehubungan dengan sasaran yang akan dinilai pada kegiatan proses belajar mengajar, c). peneliti membuat jadwal kunjungan dengan menyesuaikan jadwal pelajaran yang sudah dibuat oleh sekolah pada semester ganjil tahun pelajaran 2018/2019, d). guruguru mempersiapkan rencana pembelajarannya dan siap untuk dipantau di kelas, dan e). pada tahap ini peneliti menyampaikan fokus penilaian yang perlu diketahui oleh guru-guru yang menjadi objek tindakan. 2). Pelaksanaan tindakan dengan langkah-langkah sebagai berikut: a).peneliti melakukan kunjungan di kelas guna memantau guru-guru pada saat melakukan 
proses belajar mengajar di kelas, b). waktu yang digunakan oleh peneliti untuk memantau guru-guru yang menjadi sasaran dalam penelitian tindakan kepengawasan ini adalah dua jam pelajaran ( 2 x 45 menit) untuk setiap guru di kelas, b). kegiatan pembelajaran dimulai dengan kegiatan pendahuluan, kegiatan inti, dan kegiatan menutup pelajaran semua kegiatan tersebut tidak luput dari pemantauan yang dilakukan oleh peneliti. 3). Pengamatan dengan melakukan langkah-langkah sebagai berikut: a). guru peneliti melakukan pengamatan terhadap guru-guru untuk melihat sejauh mana pelaksanaan pembelajaran yang telah disusun dan mengimplementasikannya dalam kegiatan proses belajar mengajar di kelas, b). melakukan penilaian dengan mengisi format penilaian yang sudah disiapkan. 4). Refleksi. Pada kegiatan keempat ini guru menyampaikan hal-hal yang menjadi temuan pada saat pemantauan dilakukan, dan peneliti juga menyampaikan hal-hal yang dianggap penting untuk memperbaiki kekurangan-kekurangan guru dalam menyampaikan pembelajaran di kelas. hal ini penting demi untuk kelanjutan pada pelaksanaan tindakan selanjutnya atau pada siklus ke II. 2). Siklus II, setelah melihat kemampuan guru-guru berdasarkan hasil pantauan pada tindakan siklus I, maka peneliti atau supervisior melanjutkan kegiatan pada siklus II untuk membandingkan hasil yang telah dicapai pada siklus I yang telah dilaksanakan dengan harapan terjadi peningkatan kemampuan guru dalam mengelola pembelajaran di sekolah.

Adapun pelaksanaan tindakan kepengawasan pada siklus II yang merupakan kelanjutan dan perbaikan dari siklus I antara lain: 1). Perencanaan, dengan langkah-langkah seperti: a). peneliti menyusun dan menyampaikan rencana kepada guru-guru yang akan dipantau untuk pelaksanaan tindakan siklus II, b). guru-guru menyatakan kesiapannya dengan mengikuti jadwal atau roster mata pelajaran, c). guru-guru yang akan disurpivisi mempersiapkan diri serta membuat perangkat pembelajaran sesuai dengan bahan ajar yang akan disajikan di kelas, dan d). pada tahap ini pula peneliti menyampaikan fokus yang menjadi penilaian dalam pengamatan berdasarkan format penilaian. 2). Tahap pelaksanaan dengan langkah-langkah sebagai berikut: a). peneliti atau supervisior melakukan kunjungan di kelas guna mengamati atau memantau secara langsung pada saat guru mengajar di kelas, b). waktu yang digunakan untuk pemantauan bagi setiap guru adalah 2 jam pelajaran ( 2 X45 menit), e). penyajian materi pelajaran di kelas dilakukan dengan kegiatan pendahuluan yang meliputi apersepsi dan mencek kesiapan peserta didik dalam mengikuti pembelajaran, kegiatan inti yang meliputi kegiatan menyajikan materi pelajaran dan membuat refleksi bersama, kegiatan penutup yang meliputi kegiatan: menyimpulkan materi pelajaran yang sudah di sajikan, dan pemberian tugas. 3). Pengamatan, dalam kegiatan ini peneliti melakukan pengamatan terhadap guru-guru yang disupervisi di kelas dengan melihat secara langsung kelemahan-kelemahan serta keberhasilannya guru dalam mengelola pembelajaran. 4). Refleksi, pada kegiatan ini peneliti menyampaikan hasil temuannya terhadap guru-guru yang disupervisi kemudian memberikan bimbingan kepada guru-guru agar kelemahankelemahan yang ditemukan dapat diperbaiki sehingga proses pembelajaran dapat berlangsung dengan baik sehingga kemampuan guru dalam mengelola pembelajaran semakin mengalami peningkatan.

Hasil penelitian pada siklus II menunjukkan bahwa melalui supervisi klinik yang dilakukan oleh peneliti di kelas menggambarkan bahwa kemampuna guru dalam mengelola pembelajaran mengalami peningkatan yang signifikan hal ini terlihat dari 6 orang guru yang dipantau oleh peneliti di kelas maka terdapat 5 orang guru $(85,71 \%)$ di antaranya yang sudah mampu menyiapkan rencana pelaksanaan pembelajaran (RPP) dengan baik dan masih terdapat 1 orang guru $(14,29 \%)$ yang belum mampu menyiapkan rencana pembelajarannya, demikian pula dalam hal implementasinya dalam pelaksanaan proses belajar mengajar, 
berdasarkan hasil penilaian yang dilakukan oleh peneliti maka terdapat 5 orang guru yang memperoleh nilai antara 70-85 dengan kategori nilai tinggi (nilai B), sedangkan 1 orang guru yang masih memperoleh nilai antara 40-54 dengan kategori kurang (nilai D). Adapun penelitian ini relevan dengan dukungan hasil penelitian yang lainnya (Kamaruddin, 2021; Muhsin, 2021; Wahyuni, 2021) yang menjelaskan bahwa kegiatan supervisi yang dilakukan oleh kepala sekolah memiliki pengaruh terhadap peningkatan professional guru dalam mengelola pembelajaran di kelas.

\section{Kesimpulan}

Berdasarkan analisis data hasil penelitian dapat disimpulkan sebagai berikut; 1) Bahwa melalui supervise klinik yang dilakukan di kelas dapat meningkat kemampuan guru dalam mengelola pembelajaran di kelas hal ini terlihat dari 6 orang guru yang dipantau pada siklus I terdapat 2 orang (28.57\%) yang sudah mampu mempersiapkan RPP dengan baik, sedangkan pada siklus II terdapat 5 Orang guru $(85,71 \%)$ mengalami kenaikan 57,14\%,; 2).dilihat dari segi nilai yang diperoleh berdasarkan format penilaian yang di isi oleh peneliti juga mengalami peningkatan dimana pada siklus II terdapat 5 orang guru yang mendapat nilai dengan kategori tinggi (nilai B); dan 3) partisipasi guru untuk disupervisi di kelas sangat besar hal terlihat dari kesediaan guru-guru untuk dipantau, olehnya itu pelaksanaan supervisi sangat dirasakan manfaatnya oleh guru karena dapat meningkatkan kemampuan guru dalam mengelola pembelajaran di sekolah (di kelas).

\section{Saran}

Berdasarkan kesimpulan di atas, dapat disampaikan saran sebagai berikut: 1) Pelaksanaan supervisi di sekolah perlu dilakukan oleh kepala sekolah dan pengawas agar kegiatan pembelajaran yang dilakukan oleh guru di kelas senantiasa dapat mengurangi dan memperbaiki kekurangan dan kelemahan guru dalam proses belajar mengajar; 2) Pelaksanaan supervisi perlu dilakukan untuk meningkatkan kemampuan guru dalam mengelola pembelajaran sehingga dapat memperbaiki mutu dan kualitas pendidikan; dan 3) Hasil penelitian ke pengawasan ini dapat dijadikan sebagai dasar pengambilan kebijakan oleh kepala sekolah dan pengawas dalam rangka memperbaiki kualitas pembelajaran di sekolah.

\section{Daftar Pustaka}

Ekojuniarto. (2004). Pengembangan Silabus Jakarta: Departemen Pendidikan Nasional. Dirjen Pendidikan Dasar dan Menengah. Direktorat Tenaga Kependidikan.

Ella Yulaewati. (2004). Kurikulum dan Pembelajaran Filosofi Teori dan Aplikasinya. Bandung. Pakar Raya

Jamilan, J. (2017). Meningkatkan Kompetensi Guru Kelas dalam Proses Pembelajaran Melalui Supervisi Akademik di SD Negeri 4 Mataram. Jurnal Kependidikan: Jurnal Hasil Penelitian dan Kajian Kepustakaan di Bidang Pendidikan, Pengajaran dan Pembelajaran, 3(2). doi:https://doi.org/10.33394/jk.v3i2.675

Kamaruddin, H. (2021). Upaya Meningkatkan Kompetensi Guru SMK Negeri 4 Gowa dalam Melaksanakan Proses Pembelajaran di Kelas Melalui Program Supervisi. Jurnal Paedagogy, 8(3), 414-421. doi:https://doi.org/10.33394/jp.v8i3.3894

Kunandar. (2007). Guru Profesional: Implementasi Kurikulum Tingkat satuan Pendidikan (KTSP) dan persiapan menghadapi sertifikasi guru. Jakarta: RajaGrafindo Persada. 
Landa, Husen. (2003). Menyusun dan mengembangkan instrument Supervisi Pendidikan. Materi Pelatihan Kompetensi Pengawas. Jakarta: Departemen Pendidikan Nasional. Direktorat Lanjutan Pertama.

Muhsin, H. (2021). Academic Supervision untuk Meningkatkan Learning Design Skills Guru di Sekolah Dasar. Jurnal Paedagogy, 8(3), 282-287. doi:https://doi.org/10.33394/jp.v8i3.3823

Mulyasa, E. (2004). Kurikulum Berbasis Kompetensi. Bandung: Penerbit PT Remaja Rosdakarya.

Puskur-Balitbang. (2006). Landasan Pengembangan Silabus dan Rencana Pelaksanaan Pembelajaran. Jakarta: Departemen Pendidikan Nasional. Dirjen Pendidikan Dasar dan Menengah. Direktorat Kependidikan.

Sabirin SJ. (2011). Meningkatkan Kemampuan Guru Dalam Melaksanakan Pembelajaran di Kelas Melalui Perencanaan Pembelajaran Standar Pada SMK Negeri 3 Takalar. PTS : Pengawas Dinas DIKPORA Kabupaten Takalar

Suharsimi Arikunto, Suharjono, Supardi. (2006), Penelitian Tindakan Kelas. Jakarta; PT Bumi Aksara.

Supatni, P. (2017). Mengefektifkan Pelaksanaan Supervisi Akademik dalam Upaya Meningkatkan Kompetensi Guru Kelas dalam Proses Pembelajaran di SDN 36 Ampenan. Jurnal Kependidikan: Jurnal Hasil Penelitian dan Kajian Kepustakaan di Bidang Pendidikan, Pengajaran dan Pembelajaran, 3(1). doi:https://doi.org/10.33394/jk.v3i1.473

Wahyuni, T. (2021). Supervisi Klinis oleh Kepala Sekolah guna Meningkatkan Kompetensi Guru dalam Mengelola Administrasi Kelas di SD Negeri 42 Ampenan. Jurnal Paedagogy, 8(2), 264-270. doi:https://doi.org/10.33394/jp.v8i2.3561

Zainudin, Z. (2016). Meningkatkan Kompetensi Guru Sasaran dalam Proses Pembelajaran Melalui Supervisi Akademik di SMPN 21 Mataram. Jurnal Kependidikan: Jurnal Hasil Penelitian dan Kajian Kepustakaan di Bidang Pendidikan, Pengajaran dan Pembelajaran, 2(1). doi:https://doi.org/10.33394/jk.v2i1.451 